\title{
シンポジウム クラゲ類の大量発生とそれらを巡る生態学・生化学・利用学
}

\section{II-2. 摂慨と成長}

\section{石 井 晴 人}

東京海洋大学

II-2. Feeding behavior and growth of jellyfish

\section{HARUTO ISHII}

Tokyo University of Marine Science and Technology, Minato, Tokyo 108-8477, Japan

最近，世界の様々な海域においてクラゲ類をはじめと するゼラチン質プランクトンの大量出現が大きな問題と なっている。例えば，黒海に抢けるクシクラゲ類 Mnemiopsis leidy,1) ベーリング海におけるアカクラゲ Chrysaora melanaster,${ }^{2)}$ また最近では日本海におおる工 チゼンクラゲ Nemopilema nomurai の大量出現3)な゙゙が 大きく取り上げられている。そのなかでも，恒常的に沿 岸域に出現し，特に夏季に抢いて高密度の群れを形成す るミズクラゲ Aurelia aurita は, 4) 東京湾ではかつてほ とんど出現しなかったにもかかわらず，近年大量に発生 し, 沿岸域の社会活動や水産業に対して多大な被害をも たらしている。5,6) ここでは, クラゲ類の中でも特にミズ クラゲを中心に, その摂䭒行動や成長の特徵について, 過去の研究例や現在のデータから得られた知見について 報告するとともに，東京湾等の内湾環境の変動がどのよ うに沿岸生態系に影響してミズクラゲの増大をもたらし たのかを考察してみたい。

\section{1. 摂餌行動}

ミズクラゲの生息する内湾域は, 富栄養化の進行とそ れに伴う赤潮の頻発, 動物プランクトン現存量の増大な ぞに特徵づけられる。その中でも，小型橈脚類である Oithona davisae は，現在の東京湾で最も優占している 動物プランクトンであり, 単独で橈脚類群集中の最優占 種と言っても過言ではない。五かつては, Acartia omorii 等の中型橈脚類も数多く出現しており, 魚類等の好適な 飭料となっていた。 8 ○) しし, 魚類等の “視覚的捕食者” にとってO. davisae の体サイズは小さすぎ，結果として 飭料として利用しにくいものとなっている。

ミズクラゲは, 口腕などの体表面に付着した䬣生物を 摂䭒する “機会的捕食者”であり，その傘縁の流速から 逃避できるような遊泳力をもった生物以外は拱餌するこ とが可能である。9) すなわち, 飭料サイズ依存性の低い ミズクラゲのような捕食者にとって，小型で遊泳力の乏 しいO. davisae 群集の卓越は, 魚類等と比較して何ら負 の要因にはならず，そのまま利用可能な餌量の増加につ
ながっているのである。実際に現場海域で採集されたミ ズクラゲの胃腔内容物のほとんどは O. davisae で占めら れている。 ${ }^{10)}$ 最近では，夏季を中心として，水産上有用 なアサリ等の二枚貝の浮遊期幼生も多数胃腔内から観察 されており，その影響についても明らかにする必要があ ろう (石井, 未発表)。

\section{2. 成長}

ミズクラゲは慨の少ないときには成長速度を抑え，多 くなると非飽和的に拱慨し高い速度で生長するという柔 軟な適応能力を持つことが知られている。化欧の沿岸 域など比較的貧栄養な海域におけるミズクラゲは $10 \mathrm{~cm}$ 前後で成熟し，その後顕著な成長は観察されないが, 11) 過栄養な東京湾におけるミズクラゲの成長速度は高く, 春季に出現したエフィラ幼生は夏季までに $15 \sim 20 \mathrm{~cm}$ 程度まで成長し（図 1), 12) プラヌラ幼生をもつ。夏季 には高水温による呼吸代謝の増加と産卵活動の開始によ り成長は制限されるものの, 秋季以降は再び成長し, 12 一部の個体は翌春まで越冬し, 他の海域ではあまり見ら れない $30 \mathrm{~cm}$ を越す個体もしばしば観察される。深この ように, 東京湾ではミズクラゲの体サイズは大型化し, かつ産卵期間も長いため, 結果として生涯産卵量も飛踓

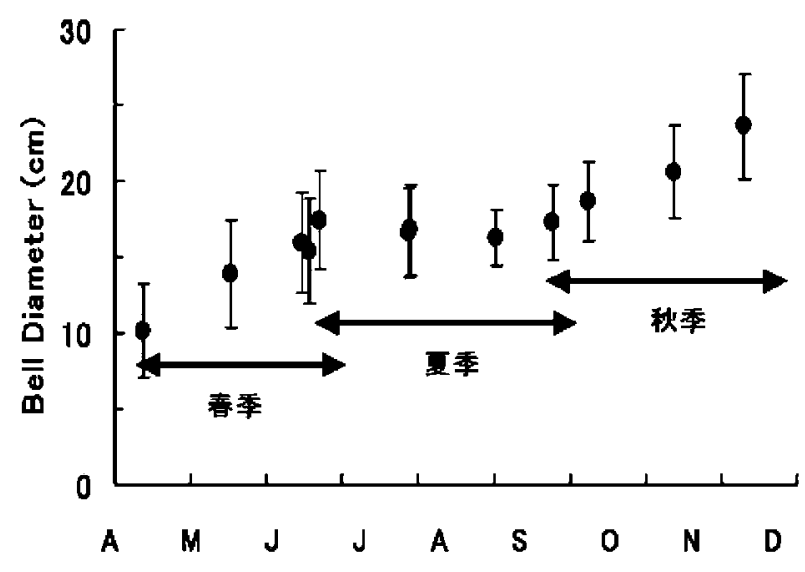

図 1 東京湾に抢けるミズクラゲの成長（平均 $\pm \mathrm{SD}$ ) 
的に大きくなることが考えられる。さらに，付着生活を するポリプ（スキフラ幼生）期の生残率が，他の付着生 物の影響をあまり受けない秋〜冬季にかけて最も高くな ることからも，13) 成体クラゲが秋季以降も生存し続け, 産卵を連続的に行っている内湾域ではミズクラゲの大量 発生が起きやすいものと推測される。

\section{3. 今後の課題}

ミズクラゲは，䬣環境の変動に巧反に適応した生物で あり，東京湾では富栄養化と並行して抢きた動物プラン クトン現存量の増加と群集構造の変化が，ミズクラゲ群 集の増大を引き起こした一因である。6)すなわち，豊富 な䭒により秋季以降も成長し続けるような個体の存在 が，次年度以降の大量出現をもたらしているものと考え られる。また今回はふれなかったが，東京湾の底層付近 で夏季に頻繁に形成される貧酸素水塊の存在はクラゲ類 にとって有利であるという報告もある。14) 以上のことか ら考えると，ミズクラゲ等の大量発生を少しでも抑制す るためには，海域への栄養塩類の負荷軽減や貧酸素水塊 の解消，さらにポリプ期に抢いて好適な付着基盤となっ ている人工護岸や繋留船舶の除去や沿岸部の砂浜化な ぞ，海洋環境全体に対する拔本的な見直しが必要である と思われる。

\section{文献}

1) Shiganova TA, Mirzoyan $Z A$, Studenikina EA, Volvik SP, Siokou-Frangou I, Zervoudaki S, Christou ED, Skirta AY, Dumont HJ. Population development of the invader ctenophore Mnemiopsis leidyi, in the Black Sea and in other seas of the Mediterranena basin. Mar. Biol. 2001; 139: 431445.

2) Brodeur RD, Sugisaki H, Hunt Jr GL. Increases in jellyfish biomass in the Bering Sea: implications for the ecosysytem. Mar. Ecol. Prog. Ser. 2002; 233: 89-103.

3）飯泉 仁. エチゼンクラゲの大量出現と水産業への影 響. 日本プランクトン学会報 2005; 52: 32-35.

4) Uye S, Fujii N, Takeoka H. Unusual aggregations of the scyphomedusa Aurelia aurita in coastal waters along western Shikoku. Plankton Biol. Ecol. 2003; 50: 17-21.

5) Omori M, Ishii H, Fujinaga A. Life history strategy of Aurelia aurita (Cnidaria, Scyphomedusae) and its impact on the zooplankton community of Tokyo Bay. ICES J. mar. Sci. 1995; 52: 597-603.

6）石井晴人. 環境変動が沿岸海洋プランクトン生態系に及 ぼす影響, 特にクラゲ類の増大に関連して。 日本プラン クトン学会報 2001; 48: 55-61.

7）穴久保隆, 村野正昭. 東京湾における動物プランクトン の季節変化. 東京水産大学研究報告 1991; 78: 145-165.

8）野村英明. 東京湾における動物プランクトンの群集構造 と遷移に関する研究. 博士論文, 東京水産大学, 東京. 1993.

9) Costello JH, Colin SP. Morphology, fluid motion and predation by the scyphomedusa Aurelia aurita. Mar. Biol. 1994; 121: 327-334.

10) Ishii H, Tanaka F. Food and feeding of Aurelia aurita in Tokyo Bay with an analysis of stomach contents and a measurement of digestion times. Hydrobiologia 2001; 451: 311-320.

11) Ishii H, Båmstedt U. Food regulation of growth and maturation in a natural population of Aurelia aurita (L.). J. Plankton Res. 1998; 20: 805-816.

12) Ishii $H$, Tanaka $F$. Respiration rates and metabolic demands of Aurelia aurita in Tokyo Bay with special reference to large medusae. Plankton Benthos Res. 2006; 1: in press.

13) Watanabe T, Ishii H. In situ estimation of ephyrae liberated from polyps of Aurelia aurita using settling plates in Tokyo Bay, Japan. Hydrobiologia 2001; 451: 247-258.

14) Breitburg DL, Rose KA, Cowan Jr JH. Linking water quality to larval survival: predation mortality of fish larvae in an oxygen-stratified water column. Mar. Ecol. Prog. Ser. 1999; 178: 39-54. 